\title{
SEASCAPE CONTEXT AS A DRIVER OF THE FISH COMMUNITY STRUCTURE OF Posido- nia oceanica MEADOWS IN THE ADRIATIC SEA
}

\author{
Ivana Zubak Čižmek ${ }^{1,2,3}{ }^{*}$, Stewart Tyre Schultz ${ }^{1,2}$, Claudia Kruschel $^{1,2}$, Hrvoje Čižmek ${ }^{3}$
}

${ }^{1}$ University of Zadar, Department of Ecology, Agronomy, and Aquaculture, Trg kneza Višeslava 9, HR-23000 Zadar, Croatia

${ }^{2}$ CIMMAR, Center for Interdisciplinary Marine and Maritime Research, University of Zadar, HR-23000 Zadar, Croatia

${ }_{3}^{3}$ Marine Explorers Society - 20000 Leagues, Put Bokanjca 26a, HR-23000 Zadar, Croatia

*Corresponding Author: izubak@unizd.hr

\section{ARTICLE INFO}

Received: 24 November 2020

Accepted: 13 March 2021
Keywords:

Seagrass

Fish

Assemblage structure

Lure-assisted underwater visual census

How to Cite

\section{ABSTRACT}

Marine underwater habitats dominated by seagrass Posidonia oceanica play an essential role in fish community assembly, affecting taxonomic and functional diversity, abundance and fish behavior. The value of seagrasses as habitat depends on the spatial arrangement of the seascape elements and the availability of alternative habitats. Little is known about the effect of the seascape context of $P$. oceanica meadows on fish assemblages in the Mediterranean Sea. To identify $P$. oceanica meadows' relative importance as a habitat for fishes, fish communities in the Croatian Adriatic Sea were investigated, using SCUBA lure-assisted visual census. The results show a significant effect of different arrangements of $P$. oceanica meadows' seascape elements and surrounding habitats on fish community structure. Fragmented mosaic meadows with $P$. oceanica growing directly on and between rocky-algal reefs/boulders had significantly higher fish abundances compared to both types of continuous meadows (bordering rock and bordering sand). Continuous meadows bordering sand harbored the highest number of unique species. Evidence that alternative structured habitats within proximity to seagrass beds may affect the community structure of associated fish assemblages is provided, highlighting the need to consider $P$. oceanica meadows' seascape context in conservation management and experimental design for fish community structure.

Zubak Čižmek, I., Schultz, S. T., Kruschel, C., Čižmek, H. (2021): Seascape context as a driver of the fish community structure of Posidonia oceanica meadows in the Adriatic Sea. Croatian Journal of Fisheries, 79, 89-109. DOI: 10.2478/cjf-2021-0011. 


\section{INTRODUCTION}

Seagrasses represent one of the most productive and diverse shallow-water marine habitats; they form extensive and dense beds with high structural complexity (Duarte and Chiscano, 1999), which increases their value as a nursery/spawning and feeding ground for many fish, invertebrate and bird species (Orth et al., 1984; Nagelkerken et al., 2001). Seagrasses are identified as being "ecosystem engineers" for providing habitat for diverse fauna and for delivering numerous ecosystem services, such as slowing down water movement, stabilizing the sediment, protecting the shores from erosion, increasing sedimentation rates, and having high denitrification, nitrogen burial and carbon burial rates (Bos et al., 2007; Eyre et al., 2011; McLeod et al., 2011). Despite their value, seagrasses are among the most endangered habitats worldwide; their decline rates are as high as those of coral reefs or mangroves (estimated loss of $110 \mathrm{~km}^{2} \mathrm{yr}^{-1}$ between 1980 and 2006) (Waycott et al., 2009). The known extent of Posidonia oceanica L. Delile 1813 within the Mediterranean in 2015 was a minimum of $12,247 \mathrm{~km}^{2}$, with an estimated loss of $10 \%$ or 1,241 $\mathrm{km}^{2}$ over the past 50 years (Telesca et al., 2015). However, the report mentioned above lacks information on the presence or absence of $P$. oceanica for almost half of the Mediterranean coastline (primarily the southeastern Mediterranean).

Posidonia oceanica is an endemic Mediterranean seagrass that forms large monospecific meadows (Hemminga and Duarte, 2000) present between the surface and 44 meters of depth (Den Hartog, 1979; Borg and Schembri, 1995; Procaccini et al., 2003). Fish assemblages associated with $P$. oceanica meadows have been well studied (Bell and Harmelin-Vivien, 1982; Francour, 1997; Moranta et al., 2006; Boudouresque et al., 2012; Zubak et al., 2017), and the high degree of spatial and temporal variation in the structure of fish assemblages have been documented (Guidetti, 2000; Deudero et al., 2008; Kalogirou et al., 2010). Existing studies of the community structure and the differences in fish assemblages focus on comparing $P$. oceanica meadows to other nearshore habitats (Mouillot et al., 1999; Guidetti, 2000). To the best of our knowledge, there are no published studies on how $P$. oceanica fish assemblages are influenced by the seascape context, especially by the surrounding or adjacent habitats. Published studies in tropical and temperate areas outside the Mediterranean region have documented interactions among seagrass, mangrove and coral reef habitats (Nakamura and Sano, 2004; Dorenbosch et al., 2006; Gilby et al., 2018). Coral reefs and mangroves affect the tropical and subtropical fish assemblages in adjacent habitats (Dorenbosch et al., 2006; Kopp et al., 2007; Olds et al., 2013). Similarly, the proximity of seagrass beds in subtropical estuaries provides complex habitats and increases the number of species and individuals in nearby habitats (Gilby et al., 2018). Species diversity and abundance of associated fauna can be positively affected by a higher habitat structural complexity (Graham and Nash, 2013; Henderson et al., 2017), and the combination of shelter, food resources and protection from predation are the main factors that shape the animal communities (Connolly and Hindell, 2006). Seagrasses can be nurseries from which juvenile fish move to adjacent habitats or serve as feeding or sheltering grounds (Nagelkerken, 2000; Dorenbosch, 2004; Nakamura and Sano, 2004). Within seagrass habitats, fish communities can be affected, among other factors, by seagrass patch size and shape (Salita et al., 2003), but also by the seascape context - the spatial organization of the various elements of the submarine landscape, including the availability of adjacent alternative structured habitats (Dorenbosch et al., 2007; Pittman et al., 2007; Unsworth et al., 2008).

Along the east coast of the Adriatic Sea (Croatia), Posidonia oceanica beds occur at depths ranging from 0 to about 36 meters on unconsolidated sediments and flat rock or rock boulders (Zubak et al., 2020). The meadows can be very diverse and most often occur as dominant habitat in one of the three types of the spatial organization of the seascape elements: (i) continuous meadows bordering bare unconsolidated sediments, (ii) continuous meadows bordering rocky algal reefs/boulders, and (iii) mosaic meadows growing on rocky algal reefs/boulders - a particular case where seagrasses grow anchored in the crevices of rocks and between rocky boulders (Fig. 1). The effects of the different seascape contexts of $P$. oceanica meadows on fish assemblage descriptors were predicted. The idea that individual fish species exhibit significant differences in $P$. oceanica meadows' preference depending on the meadows' seascape context was proposed to test the null hypotheses that there were no differences in species composition, species richness and abundance of fish assemblages occurring over different seascape contexts of $P$. oceanica meadows.

\section{MATERIALS AND METHODS}

\section{Survey locations and methods}

Fish assemblages within seagrass meadows of Posidonia oceanica were surveyed during 2011 (June-September) and 2012 (March-September), along the eastern coast of the Adriatic Sea, Croatia (Fig. 2). Fifty-five lure-assisted visual census belt transects (details in S1 Table) were performed, following the procedure described in Kruschel and Schultz (2010, 2012), using SCUBA diving along 10-meter isobaths. All transects were performed during the daytime, with calm waters, no wind (0-1 Beaufort), and at high underwater visibility $(>15 \mathrm{~m})$.

The diver (always the same individual observer, IZČ) moved along each georeferenced transect (Garmin GPSMAP 60CSx Handheld GPS Navigator attached to a buoy above the diver) and observed and recorded all fishes appearing within a water column defined by its 

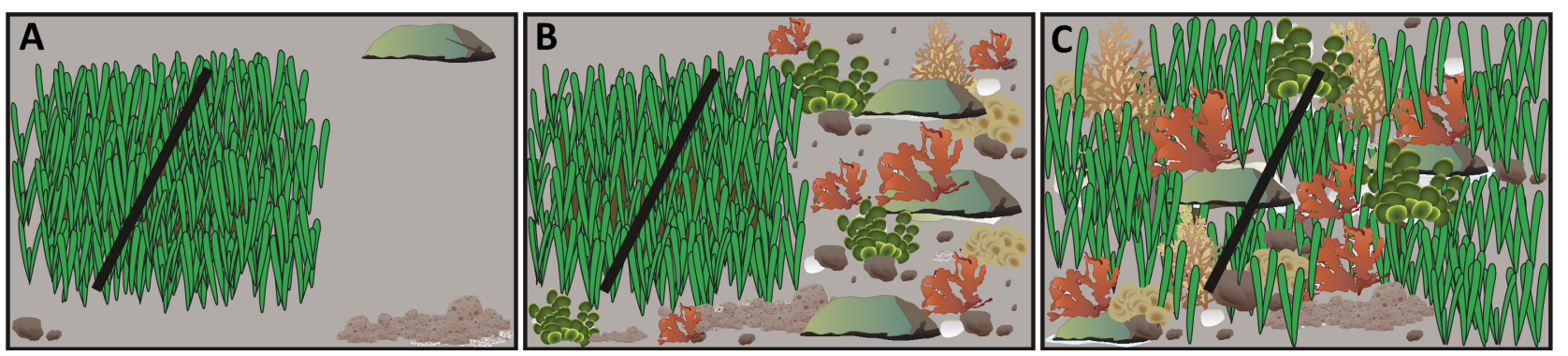

Fig 1. Three spatial organization types of Posidonia oceanica seascape elements.

A: Continuous meadow bordering sand. B: Continuous meadow bordering rocky-algal reef. C: Posidonia oceanica mosaic meadow on rocky substrates and between boulders with macro-algae. The thick black line represents a single transect performed within each of the surveyed meadows (illustration created by Ivana Zubak Čižmek with the courtesy of the Integration and Application Network, University of Maryland Center for Environmental Science (ian.umces.edu/ symbols/); authors: Diana Kleine, Joanna Woerner, and Tracey Saxby)

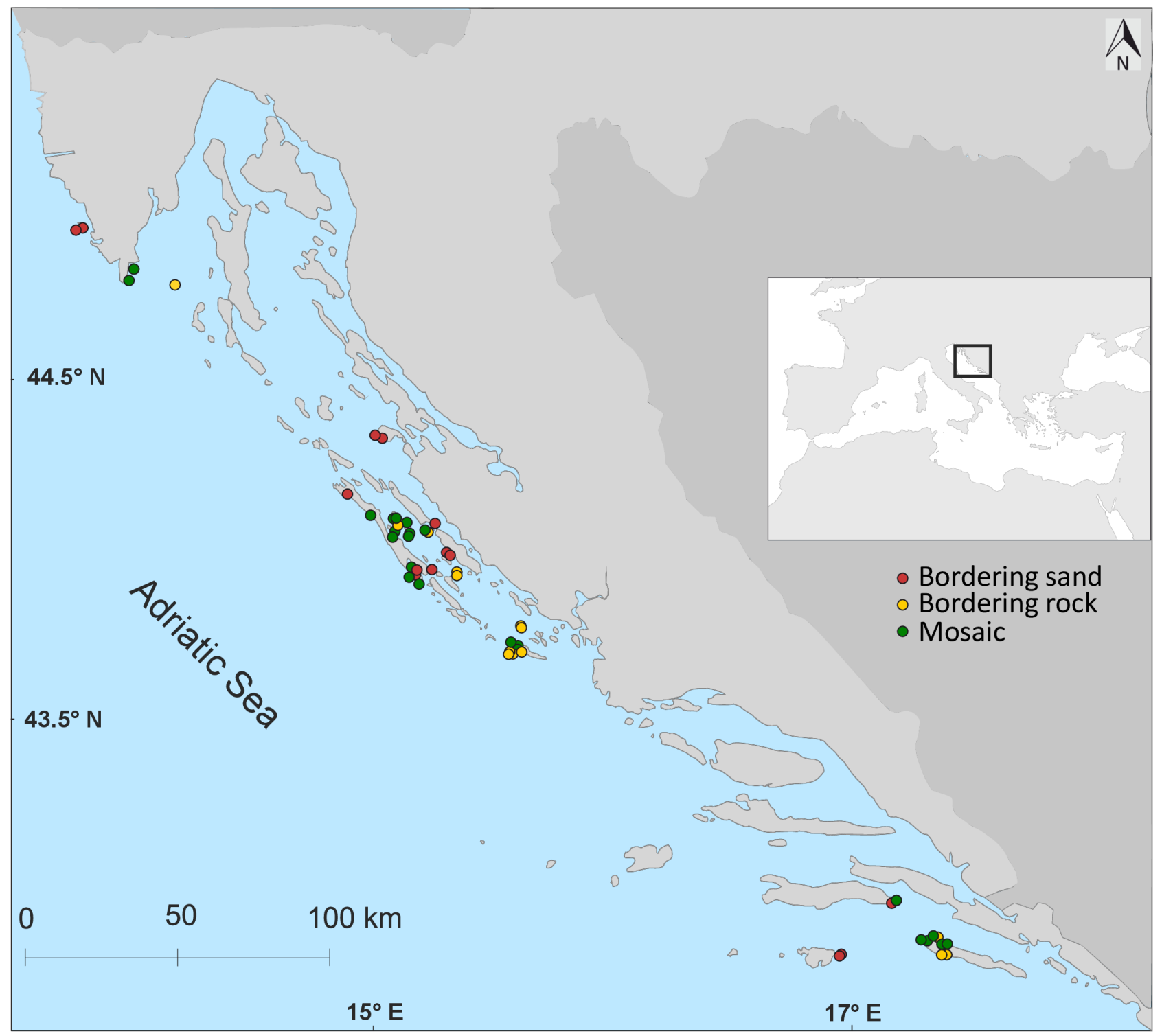

Fig 2. Locations of surveyed fish assemblages within Posidonia oceanica seagrass meadows in the Eastern Adriatic Sea, Croatia 
width ( $1 \mathrm{~m}$ to both sides of the lure line's path) and the height (extending from the bottom upward to the diver's eyes, approximately $2 \mathrm{~m})$. The lure was a small $(2 * 1 \mathrm{~cm})$ piece of lead tied to a $2 \mathrm{~m}$ long fishing line, wrapped around a Styrofoam ${ }^{\circledR}$ board. The lure was positioned and moved approximately $5 \mathrm{~cm}$ above the substrate's surface. The transects were time standardized to 10 minutes (the length varied between 61 and 99 m; mean 79.88 m (SD 11.05)). Time standardized transects were chosen because lure use requires sufficient time to allow fish to approach the lure. If transects varied in timespan, the error variance in the abundance of approaching fish would increase, and if transects tended to occupy different time spans in different habitats, then timespan would be a confounding factor with habitat. The addition of a lure to visual fish counts along transects increases the probabilities to see fishes and reduces bias due to differences in size, mobility, tendency to hide/camouflage (Kruschel and Schultz, 2010, 2012). The diver took the following data on individual fish along each transect: taxon (usually species level), developmental stage (adult/juvenile), and abundance. In some analyses, juvenile fish were treated as being different from their conspecific adults since it has been shown that many differences in fish behavior (habitat selection, feeding, anti-predator response) may depend on the ontogenetic stage (Jones, 1984; Laegdsgaard and Johnson, 2001). If the observed individuals were grouping/schooling, individual fish observations were considered non-independent; such groups were defined as two or more individuals of the same taxon observed at the same moment (i.e., observations). Individuals were counted to 20 fish, while abundance in larger groups was estimated in increments of 10 up to 100 fish and in increments of 100 up to the maximum observed group size of 200. The diver simultaneously recorded the visually estimated proportion of $P$. oceanica cover ( $\mathrm{p} 1<$ $25 \%, 25 \%<\mathrm{p} 2 \leq 50 \%, 50 \%<\mathrm{p} 3 \leq 75 \%, 75 \%<\mathrm{p} 4 \leq 100 \%)$ for each transect. The height of the $P$. oceanica canopy was uniform across all transects (approximately $80 \mathrm{~cm}$ ). Other predictor variables that potentially influence the fish assemblage structure included seawater temperature $\left({ }^{\circ} \mathrm{C}\right)$, the shore's slope calculated from the distance to the shore and transect depth $\left({ }^{\circ}\right)$, and coastline geography (embayment vs. open shore). Fish assemblages were characterized by documenting the absolute and relative abundance of adult and juvenile fish, fish taxonomic diversity, and fish species composition.

\section{Data analysis}

All statistical analyses were conducted using R v.3.4.2. (R Development Core Team and R Core Team, 2017) and RStudio 1.1.383. For all analyses, significance levels were set at $\alpha=0.05$. Analysis of variance (ANOVA) using the aov function (Chambers et al., 2017) was performed to test for differences in abundance and richness among the three different seascape contexts of Posidonia oceanica meadows, among the different $P$. oceanica covers and among different temperature values. The analyses were based on a one-way model and the residuals were checked for normality using the Shapiro-Wilk test. Tukey HSD posthoc test using the TukeyC and TukeyHSD functions (Faria et al., 2018) was performed to explore the differences in the abundance among all pairs of levels of the selected factor (e.g., seascape context).

Because transects varied in length and were time standardized, abundance was expressed and analyzed as the abundance per $\mathrm{m}^{3}$ of each transect $\left(\mathrm{m}^{3}\right.$; volume $=$ length $*$ width $(2 \mathrm{~m}) *$ height $(2 \mathrm{~m}))$. To compare fish assemblages found associated with the three different seascape contexts of $P$. oceanica meadows, permutational multivariate analysis of variance, PERMANOVA (Anderson, 2001; McArdle and Anderson, 2001) was used, which is a non-parametric confirmatory statistics method. The predictor variables of interest were the meadow's seascape context (bordering bare sand, bordering rockyalgal reefs, or mosaic rocky-algal substratum), P. oceanica cover, and temperature. The response matrix was the matrix of relative fish abundances in each community at each transect, with the transect being the statistical sample replicate $(N=55)$. The fish community matrix was converted to the Bray-Curtis distance matrix before analysis. The similarities among communities grouped by the primary predictor variable (seascape context of the meadow) were presented visually with unconstrained, non-metric multidimensional scaling using Bray-Curtis distances; double Wisconsin standardization was used and the solution with the lowest stress was reported; 2D nMDS, using the metaMDS function in the vegan package of R (Faith et al., 1987; Minchin, 1987). The variation in the abundance of each species within and among the meadows' seascape contexts was further partitioned, using an analysis of deviance for the generalized linear (quassi-Poisson) model.

\section{RESULTS}

\section{The diversity and abundance of fishes}

A total of 2010 observations of 6842 fish individuals belonging to 45 taxa (59 when treating juveniles differently from their conspecific adults) were identified in the Posidonia oceanica meadows in the Croatian Adriatic Sea. Fifteen fish families were recorded and, in terms of species richness, Labridae, Gobiidae and Sparidae were the most diverse, with 12, 9 and 7 recorded taxa, respectively. Labridae and Sparidae contained $73 \%$ of all observed individuals (Table 1).

The most frequently recorded species in the whole dataset (including juveniles) were Coris julis (394 observations of 495 individuals), Symphodus ocellatus (364 observations of 778 individuals), Chromis chromis (155 observations of 2740 individuals) and Diplodus annularis (117 observations of 129 individuals). Nine taxa were observed on a single occasion (Table 2). 
Table 1. The total number of fish observations, the number of recorded taxa in each fish family and their relative abundances observed in Posidonia oceanica meadows in the Adriatic Sea, Croatia. Abbreviated taxa names are given in the parentheses following the full taxon name

\begin{tabular}{|c|c|c|c|}
\hline Family & Taxon & N observations & Relative abundance \\
\hline \multirow[t]{13}{*}{ Labridae (12) } & Total & 1021 & 0.508 \\
\hline & Coris julis (coju) & 394 & \\
\hline & Symphodus cinereus (syci) & 93 & \\
\hline & Symphodus doderleini (sydo) & 17 & \\
\hline & Symphodus melanocercus (symel) & 84 & \\
\hline & Symphodus mediterraneus (seme) & 25 & \\
\hline & Symphodus melops (symelo) & 8 & \\
\hline & Symphodus sp. & 12 & \\
\hline & Symphodus ocellatus (syoc) & 364 & \\
\hline & Symphodus roissali (syro) & 2 & \\
\hline & Symphodus rostratus (syros) & 11 & \\
\hline & Symphodus tinca (syti) & 9 & \\
\hline & Thalassoma pavo (thpa) & 2 & \\
\hline \multirow[t]{8}{*}{ Sparidae (7) } & & 393 & 0.196 \\
\hline & Boops boops (bobo) & 50 & \\
\hline & Diplodus annularis (dian) & 117 & \\
\hline & Diplodus vulgaris (divu) & 90 & \\
\hline & Oblada melanura (obme) & 85 & \\
\hline & Sarpa salpa (sasa) & 2 & \\
\hline & Sparus aurata (spaau) & 7 & \\
\hline & Spondyliosoma cantharus (spca) & 42 & \\
\hline \multirow[t]{4}{*}{ Serranidae (3) } & & 176 & 0.088 \\
\hline & Serranus cabrilla (seca) & 43 & \\
\hline & Serranus hepatus (sehe) & 33 & \\
\hline & Serranus scriba (sesc) & 100 & \\
\hline \multirow[t]{2}{*}{ Pomacentridae (1) } & & 155 & 0.077 \\
\hline & Chromis chromis (chch) & 155 & \\
\hline \multirow[t]{3}{*}{ Centracanthidae (2) } & & 136 & 0.068 \\
\hline & Spicara maena (spma) & 62 & \\
\hline & Spicara smaris (spsm) & 74 & \\
\hline
\end{tabular}




\section{Continued}

\begin{tabular}{|c|c|c|c|}
\hline Family & Taxon & N observations & Relative abundance \\
\hline \multirow[t]{10}{*}{ Gobiidae (9) } & & 63 & 0.031 \\
\hline & Gobius sp. & 15 & \\
\hline & Gobius bucchichi/incognitus (gobu) & 23 & \\
\hline & Gobius cruentatus (gocr) & 8 & \\
\hline & Gobius fallax (gofa) & 2 & \\
\hline & Gobius geniporus (goge) & 3 & \\
\hline & Gobius auratus (goau) & 1 & \\
\hline & Gobius niger (goni) & 1 & \\
\hline & Gobius vittatus (govi) & 8 & \\
\hline & Pomatoschistus sp. & 2 & \\
\hline \multirow[t]{2}{*}{ Mullidae (1) } & & 13 & 0.006 \\
\hline & Mullus surmuletus (musu) & 13 & \\
\hline \multirow[t]{2}{*}{ Blennidae (1) } & & 5 & 0.002 \\
\hline & Parablennius sp. & 5 & \\
\hline \multirow[t]{4}{*}{ Scorpaenidae (3) } & & 4 & 0.002 \\
\hline & Scorpaena notata (scno) & 2 & \\
\hline & Scorpaena porcus (scpo) & 1 & \\
\hline & Scorpaena scrofa (scsc) & 1 & \\
\hline \multirow[t]{2}{*}{ Atherinidae (1) } & & 1 & $<0.001$ \\
\hline & Atherina hepsetus (athe) & 1 & \\
\hline \multirow[t]{2}{*}{ Carangidae (1) } & & 1 & $<0.001$ \\
\hline & Seriola dumerili (sedu) & 1 & \\
\hline \multirow[t]{2}{*}{ Congeridae (1) } & & 1 & $<0.001$ \\
\hline & Conger conger (coco) & 1 & \\
\hline \multirow[t]{2}{*}{ Moronidae (1) } & & 1 & $<0.001$ \\
\hline & Dicentrarchus labrax (dila) & 1 & \\
\hline \multirow[t]{2}{*}{ Muraenidae (1) } & & 1 & $<0.001$ \\
\hline & Muraena helena (muhe) & 1 & \\
\hline Unidentified & & 39 & 0.019 \\
\hline Total (45) & & 2010 & \\
\hline
\end{tabular}


Table 2. Taxa observed exclusively in one seascape context (bordering sand/bordering rock/mosaic) of Posidonia oceanica meadows, observed on more than one occasion (their abundance is shown in parentheses)

\begin{tabular}{lll}
\hline \hline & \multicolumn{1}{c}{ Seascape context } & Mosaic \\
\hline Bordering sand & Bordering rock & Scorpaena notata (2) \\
\hline Mullus surmuletus (13) & & \\
Symphodus melops (8) & \\
Spondyliosoma cantharus juv. (6) & \\
Pomatoschistus sp. (2) & \\
Sarpa salpa (2) & \\
Symphodus rostratus (2) & \\
Thalassoma pavo (2)
\end{tabular}

The abundance of recorded fish varied significantly between the three seascape contexts of the $P$. oceanica meadows (Table 3, $p=0.009, F=5.128$ ); it was higher in mosaic meadows than in the meadows bordering sand and meadows bordering rock (Fig. 3). A statistically significant difference was found between mosaic meadows and meadows bordering rock (Tukey $p=0.032$ ), and between mosaic meadows and meadows bordering sand (Tukey $p=0.011)$. There was no significant difference in the abundance per $\mathrm{m}^{3}$ between the two types of continuous meadows (Tukey $p=0.999$ ).

No statistically significant difference was observed in species richness between the three observed seascape contexts of $P$. oceanica meadows $(p=2.24, \mathrm{~F}=1.48)$. The highest species richness and abundance were observed at the following sites: Fulija West (91 observations of 285 individuals belonging to 22 taxa), Žut (53 observations of 256 individuals belonging to 19 taxa) and Galijola (86 observations of 836 individuals belonging to 17 taxa). The transects mentioned above were all placed in mosaic $P$. oceanica meadows.

\section{Community structure in three meadow types}

All three seascape contexts of the $P$. oceanica meadows shared a species pool; 25 of 59 taxa (42\% including juveniles) co-occurred in the three meadow types and the meadows bordering sand had the highest number of unique taxa (Fig. 4).

Analysis of the fish community using nMDS showed the separation of three seascape contexts of the meadows (Fig. 5), with nMDS stress 0.20. Further analysis showed that 11 taxa showed significant variation in the abundance across the meadow types (Table 4).

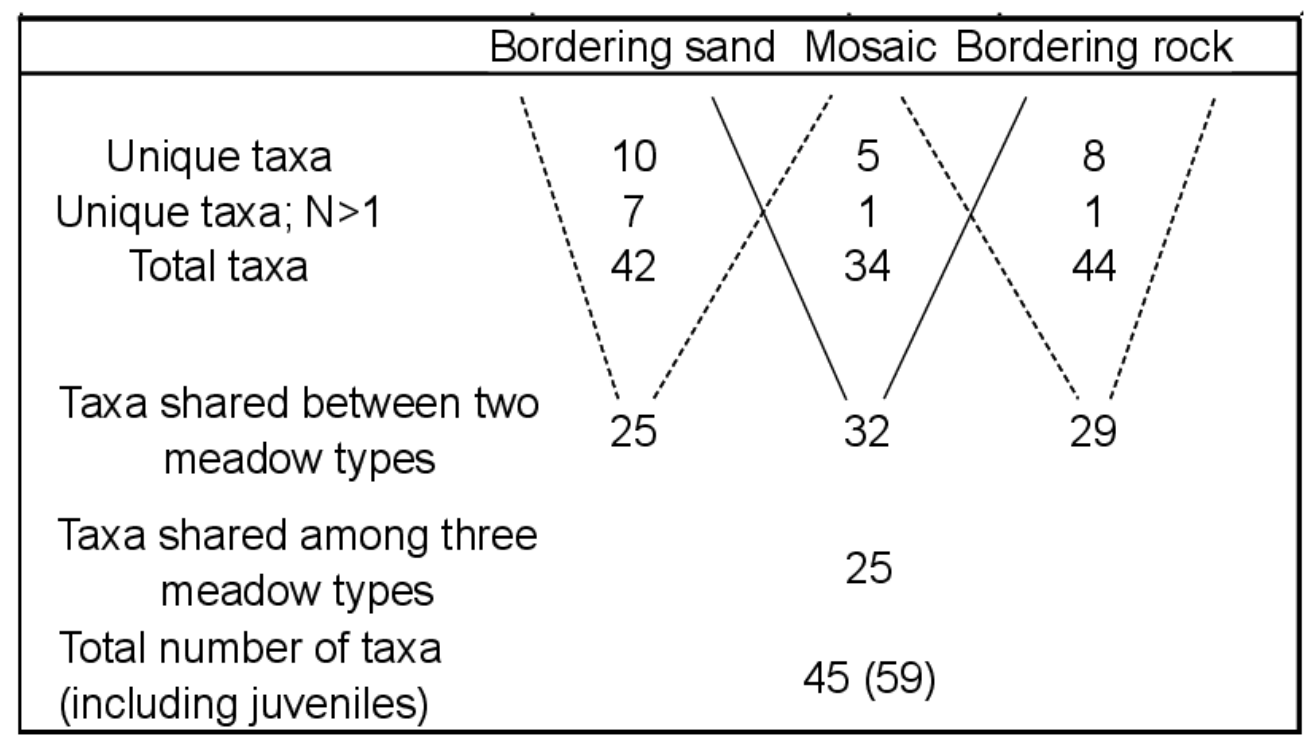

Fig 3. Box plot of abundance per volume unit $\left(\mathrm{m}^{3}\right)$ of fish in each of the three seascape contexts (bordering sand/ bordering rock/mosaic) of Posidonia oceanica meadows. Box plots show the median (line near the center), the first and third quartile (the box), the extreme values whose distance from the box is at most 1.5 times the interquartile range (whiskers) and remaining outliers (black dots) 
Table 3. Analysis of variance using ANOVA of fish abundance per $\mathrm{m}^{3}$, across three different seascape contexts of Posidonia oceanica meadows in the Adriatic Sea, Croatia (Df - degrees of freedom, SS - Sums of squares, MS - Mean Sums of squares)

\begin{tabular}{lcccccc}
\hline \hline Response: abundance (per volume unit; $\mathbf{m}^{3}$ ) & Df & Ss & Ms & F value & P \\
\hline Meadow & 2 & 0.036 & 0.018 & 5.128 & 0.009 & $* *$ \\
Residuals & 52 & 0.184 & 0.004 & & & \\
\hline \hline
\end{tabular}

${ }^{*} p<.05 ; * * p<.01 ; * * p<.001$

Table 4. Fish taxa observed within Posidonia oceanica meadows in the Adriatic Sea, Croatia, their ordination coordinates, deviance values in the analysis of deviance of abundance across different seascape contexts and associated null probability values (taxa with an asterisk sign showed a significant abundance variation across the $P$. oceanica seascape contexts; $p<0.05$ shown in bold)

\begin{tabular}{|c|c|c|c|c|}
\hline Taxon & NMDS1 & NMDS2 & deviance value & $p$ \\
\hline Atherina hepsetus & 0.599 & -0.801 & 0.509 & 0.604 \\
\hline Boops boops & 0.96 & -0.281 & 2.362 & 0.104 \\
\hline Chromis chromis & -0.837 & 0.546 & 2.778 & 0.071 \\
\hline Chromis chromis juvenile & -0.962 & -0.273 & 1.491 & 0.235 \\
\hline Conger conger & 0.972 & -0.233 & 0.509 & 0.604 \\
\hline Coris julis & -0.867 & -0.499 & 3.104 & 0.053 \\
\hline Coris julis juvenile & -0.161 & -0.987 & 1.883 & 0.162 \\
\hline Diplodus annularis* & 0.447 & 0.894 & 8.657 & 0.001 \\
\hline Diplodus annularis juvenile* & 0.33 & 0.944 & 5.781 & 0.005 \\
\hline Dicentrarchus labrax & 0.761 & 0.649 & 1.491 & 0.235 \\
\hline Diplodus vulgaris & -0.065 & 0.998 & 1.907 & 0.159 \\
\hline Diplodus vulgaris juvenile & 0.879 & -0.477 & 0.829 & 0.442 \\
\hline Gobius sp. & 0.998 & 0.061 & 1.028 & 0.365 \\
\hline Gobius sp. juvenile & 0.637 & 0.771 & 1.539 & 0.224 \\
\hline Gobius bucchichi/incognitus* & 0.682 & 0.731 & 3.177 & 0.05 \\
\hline Gobius bucchichi juvenile & -0.768 & 0.64 & 1.491 & 0.235 \\
\hline Gobius cruentatus & 0.644 & 0.765 & 0.449 & 0.641 \\
\hline Gobius fallax & 0.233 & -0.973 & 0.347 & 0.709 \\
\hline Gobius geniporus & 0.554 & 0.833 & 1.95 & 0.152 \\
\hline Gobius auratus & 0.998 & 0.059 & 1.491 & 0.235 \\
\hline Gobius niger & 0.841 & 0.542 & 0.509 & 0.604 \\
\hline Gobius vittatus & 0.392 & -0.92 & 1.262 & 0.292 \\
\hline Muraena helena & -0.962 & -0.273 & 1.491 & 0.235 \\
\hline Mullus surmuletus* & 0.009 & 0.999 & 20.003 & 0 \\
\hline Oblada melanura & -0.999 & -0.024 & 0.731 & 0.486 \\
\hline
\end{tabular}


Continued

\begin{tabular}{|c|c|c|c|c|}
\hline Taxon & NMDS1 & NMDS2 & deviance value & $p$ \\
\hline Oblada melanura juvenile & 0.982 & -0.189 & 0.881 & 0.42 \\
\hline Parablennius sp. & -0.793 & -0.609 & 2.915 & 0.063 \\
\hline Pomatoschistus sp. & -0.137 & 0.991 & 1.491 & 0.235 \\
\hline Sarpa salpa & -0.552 & 0.834 & 1.491 & 0.235 \\
\hline Scorpaena notata & -0.883 & -0.47 & 2.701 & 0.077 \\
\hline Scorpaena porcus & -0.937 & -0.35 & 1.491 & 0.235 \\
\hline Scorpaena scrofa & 0.594 & -0.804 & 0.509 & 0.604 \\
\hline Serranus cabrilla* & -0.998 & -0.07 & 15.483 & 0 \\
\hline Seriola dumerili & -1 & 0.02 & 0.509 & 0.604 \\
\hline Serranus hepatus & 0.992 & -0.129 & 1.278 & 0.287 \\
\hline Serranus hepatus juvenile & 0.234 & -0.972 & 0.509 & 0.604 \\
\hline Serranus scriba & -0.69 & 0.724 & 2.515 & 0.091 \\
\hline Serranus scriba juvenile & -0.999 & 0.02 & 0.509 & 0.604 \\
\hline Sparus aurata & -0.522 & 0.853 & 0.926 & 0.402 \\
\hline Spondyliosoma cantharus* & -0.858 & 0.513 & 7.929 & 0.001 \\
\hline Spondyliosoma cantharus juvenile* & -0.982 & -0.187 & 3.526 & 0.037 \\
\hline Spicara maena & -0.054 & 0.999 & 0.602 & 0.551 \\
\hline Spicara smaris & 0.378 & 0.926 & 0.685 & 0.509 \\
\hline Spicara smaris juvenile & -0.992 & 0.13 & 1.491 & 0.235 \\
\hline Symphodus cinereus* & 0.985 & 0.171 & 6.587 & 0.003 \\
\hline Symphodus doderleini & 0.082 & -0.997 & 1.57 & 0.218 \\
\hline Symphodus melanocercus & -0.558 & -0.83 & 2.979 & 0.06 \\
\hline Symphodus mediterraneus & -0.749 & 0.662 & 0.072 & 0.931 \\
\hline Symphodus melops* & -0.723 & 0.691 & 6.428 & 0.003 \\
\hline Symphodus sp. & 0.216 & -0.976 & 0.573 & 0.567 \\
\hline Symphodus sp. juvenile & 0.167 & -0.986 & 1.366 & 0.264 \\
\hline Symphodus ocellatus* & 0.625 & -0.781 & 9.563 & 0 \\
\hline Symphodus ocellatus juvenile & -0.967 & -0.255 & 2.772 & 0.072 \\
\hline Symphodus roissali* & -0.537 & 0.844 & 3.225 & 0.048 \\
\hline Symphodus rostratus & 0.247 & 0.969 & 0.226 & 0.799 \\
\hline Symphodus tinca & -0.591 & 0.807 & 2.19 & 0.122 \\
\hline Thalassoma pavo & -0.516 & 0.857 & 1.491 & 0.235 \\
\hline
\end{tabular}




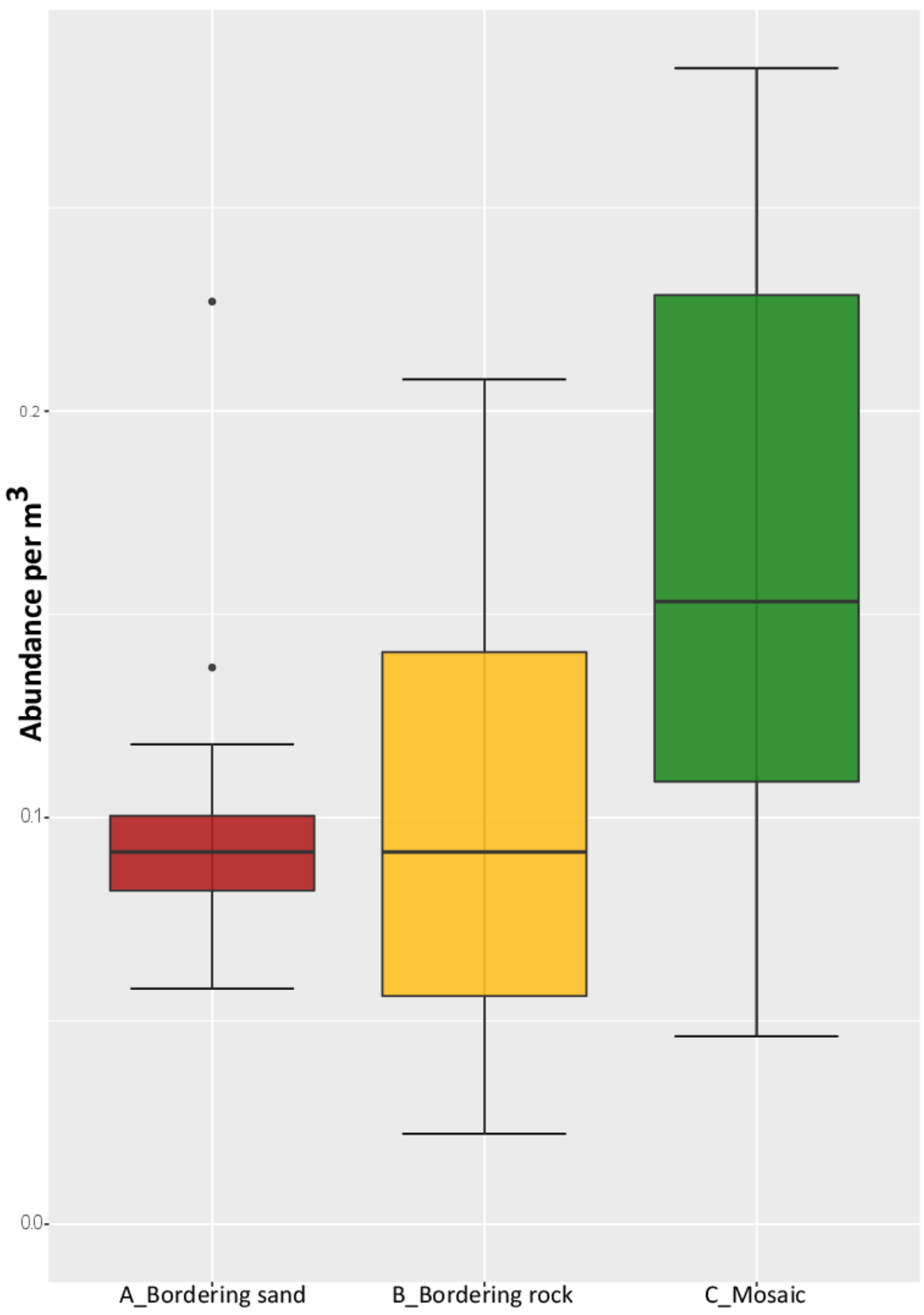

Fig 4. Total, shared and unique fish taxa across three different seascape contexts (bordering sand/bordering rock/ mosaic) of Posidonia oceanica meadows in the Adriatic Sea, Croatia

PERMANOVA results indicate a significant individual influence of seascape context, seagrass cover and temperature on fish community structure variation with no interaction between the predictor variables (Table 5). The primary variable of interest, the meadow's seascape context, explained approximately $13 \%$ of the fish community structure variability (PERMANOVA $R^{2}=0.13$, $p<0.01)$. Although the seagrass cover and temperature showed no significant effect on species richness or abundance, they were included as covariates in the PERMANOVA analysis to control potential interaction with the primary variable of interest.
The relative abundance of each of the 20 selected taxa across different $P$. oceanica meadows' seascape contexts is presented in Fig. 6 . Twenty taxa chosen for this analysis either showed a highly significant abundance variation across the three different seascape contexts of $P$. oceanica meadows (11 taxa) or had a high overall abundance ( 9 taxa).

The proportions of the most abundant species in each of the three different seascape contexts of $P$. oceanica meadows showed that Coris julis and Chromis chromis are among the four most abundant species in all meadow types (Fig 7). 


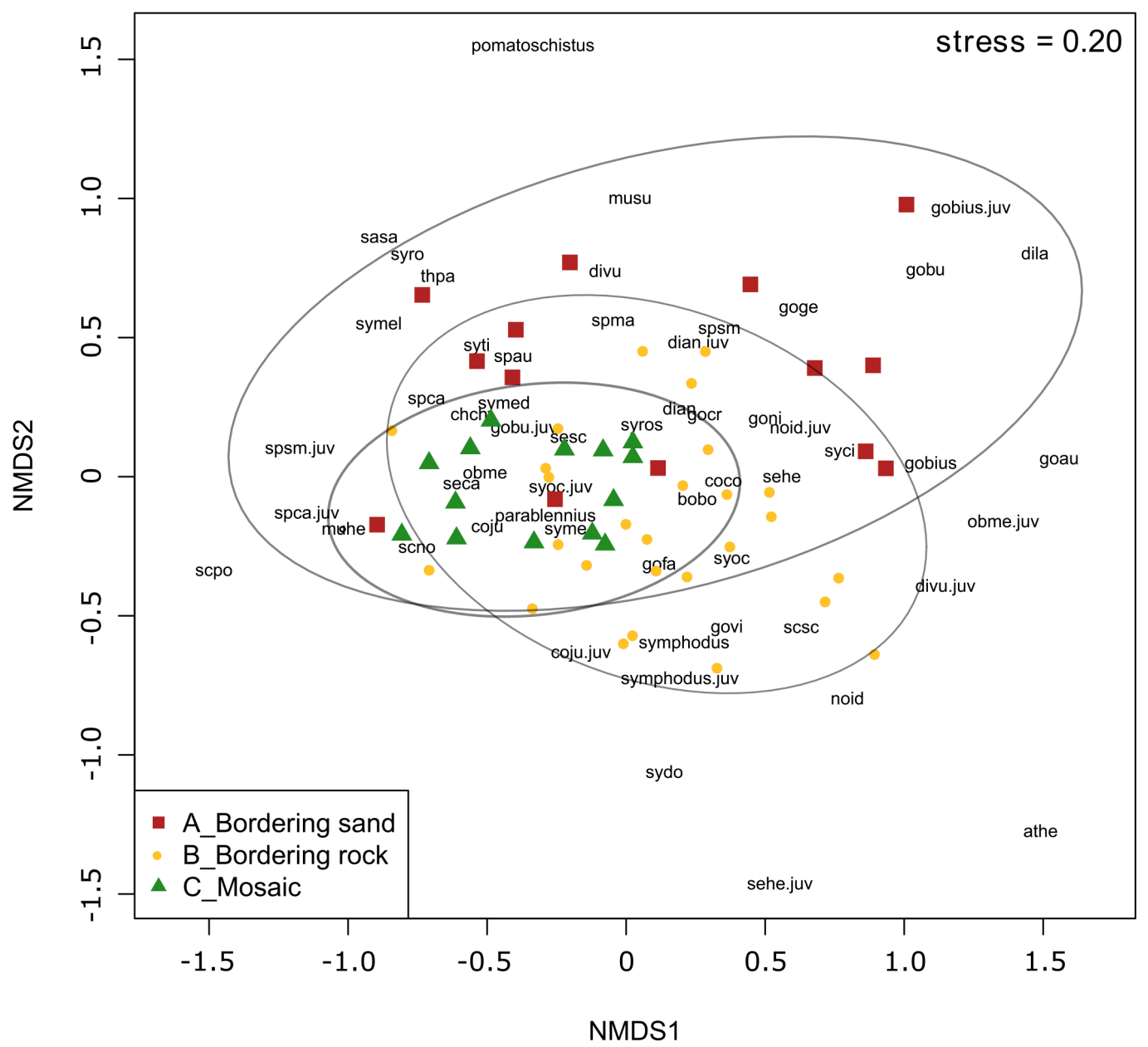

Fig 5. Two-dimensional non-metric multidimensional scaling plots of the fish community across three different seascape contexts (bordering sand/bordering rock/mosaic) of Posidonia oceanica meadows in the Adriatic Sea, Croatia. The symbols represent individual transects within the datasets indexed in Table S1. Bray-Curtis distance, final stress $=0.20$. Ellipses show 95\% confidence limits for the delimitation of each group. For species/taxa abbreviations see Table 1.

Table 5. Analysis of variance using PERMANOVA of the effect of the temperature, cover, seascape context (SC) and their interactions on the variability in Posidonia oceanica fish community structure in the Adriatic Sea, Croatia (Df - degrees of freedom, SS - Sums of squares, MS - Mean Sums of squares)

\begin{tabular}{|c|c|c|c|c|c|c|c|}
\hline & Df & SS & MS & F model & $\mathbf{R}^{2}$ & $p$ & \\
\hline Temperature & 1 & 0.543 & 0.543 & 3.333 & 0.047 & 0.003 & $* *$ \\
\hline Cover & 2 & 1.060 & 0.530 & 3.254 & 0.092 & 0.001 & $* * *$ \\
\hline SC & 2 & 1.496 & 0.748 & 4.593 & 0.130 & 0.001 & $* * *$ \\
\hline Temperature:cover & 2 & 0.424 & 0.212 & 1.302 & 0.037 & 0.177 & \\
\hline Temperature:SC & 2 & 0.413 & 0.206 & 1.268 & 0.036 & 0.195 & \\
\hline Cover:SC & 4 & 0.784 & 0.196 & 1.203 & 0.068 & 0.184 & \\
\hline Temperature:Cover:SC & 3 & 0.643 & 0.214 & 1.317 & 0.056 & 0.125 & \\
\hline Residuals & 38 & 6.187 & 0.163 & & 0.536 & & \\
\hline Total & 54 & 11.549 & & & 1 & & \\
\hline
\end{tabular}

${ }^{*} p<.05 ;{ }^{*} p<.01 ; * * * p .001$ 


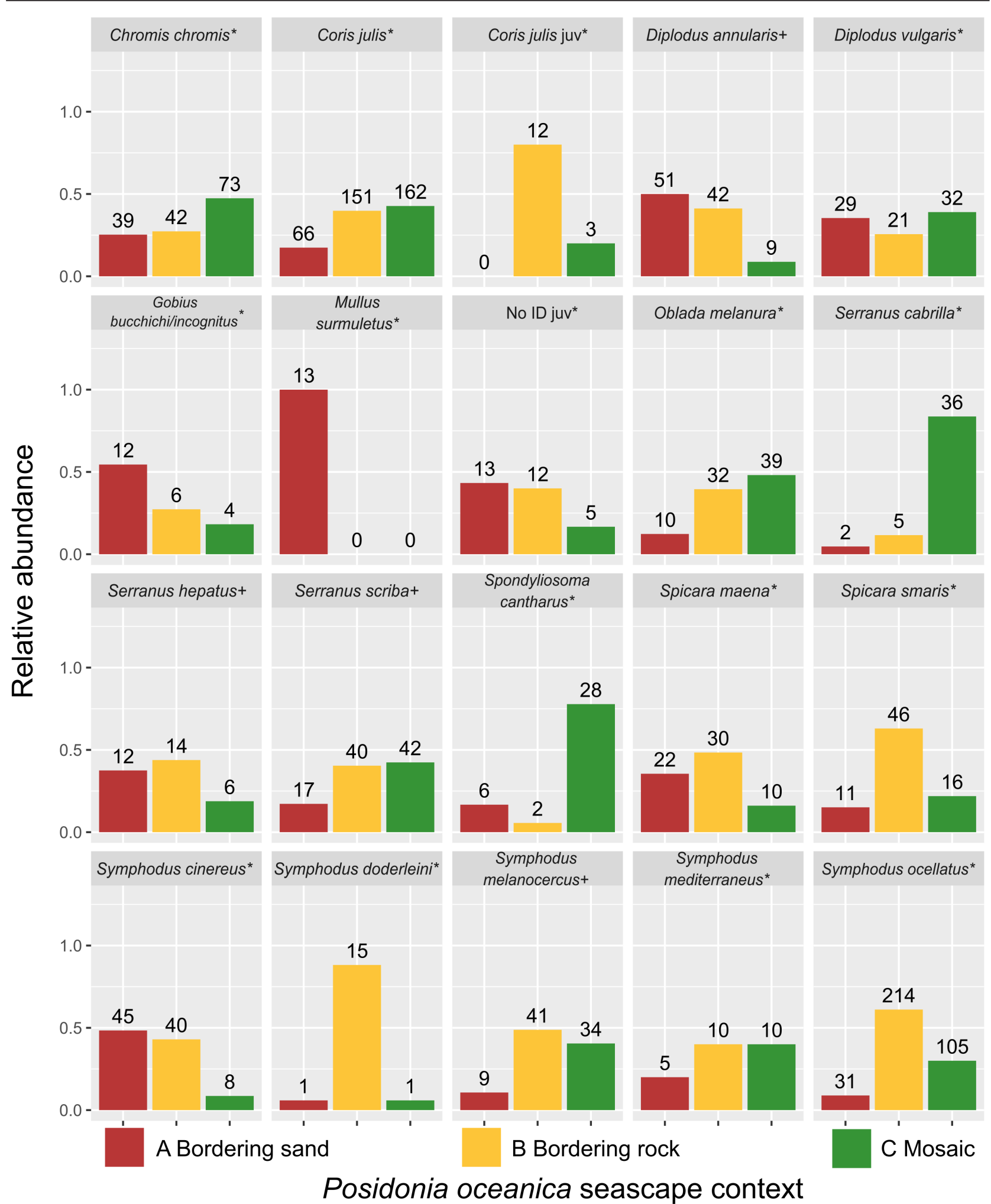

Fig 6. Bar plot showing the relative abundance of twenty selected fish species across different Posidonia oceanica seascape contexts (bordering sand/bordering rock/mosaic). Species with an asterisk showed a significant abundance variation across $P$. oceanica seascape contexts, and species with a plus sign were among the most abundant species overall. The numbers above the bars indicate each taxon's absolute abundance in the three $P$. oceanica seascape contexts. 


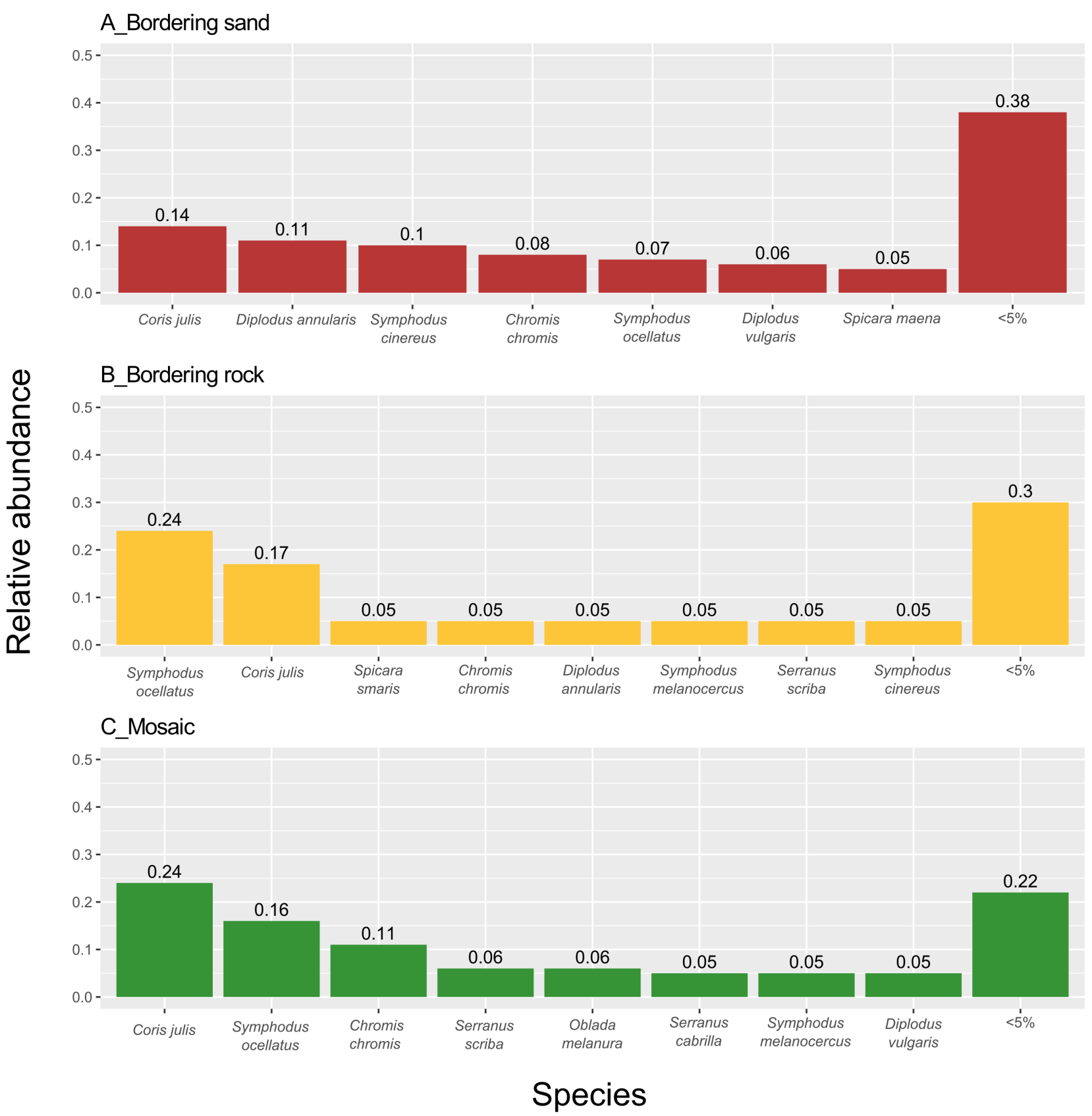

Fig 7. Bar plot showing the proportion of most abundant fish species in each of the three Posidonia oceanica seascape contexts (bordering sand/bordering rock/mosaic). The numbers above the bars indicate each taxon's relative abundance in the three seascape contexts. Species whose relative abundances were $<5 \%$ were pooled. 


\section{DISCUSSION}

\section{The fish assemblage of Posidonia oceanica meadows}

This research indicates that Posidonia oceanica ichthyofauna in all explored seascape contexts is relatively homogeneous and shares a species pool. However, statistically significant differences in fish community structure across the three different seascape contexts of $P$. oceanica meadows were found, and 11 taxa with significant differences in abundance across seagrass structural arrangements were discovered.

The total number of recorded taxa (45) was somewhat higher than previously described in other Mediterranean areas (at similar depth and using visual census): 38 from the Balearic Islands (Frau et al., 2003), 37 from Alicante, Spain (Valle and Bayle-Sempere, 2009), 35 from the Ligurian Sea (Tunesi and Vacchi, 1993) and 34 from Otranto, Apulian coast (Guidetti, 2000). The higher number of recorded taxa is probably because the lureassisted visual census was used (Kruschel and Schultz, 2012). Visual counts facilitated by a device to lure out fish from their hideout into the view of the diver can significantly improve the probability of detecting small fish hidden within the seagrass canopy, predators that search for and encounter prey from a concealed position (e.g., ambush predators and wait-chase predators) or fast cruising predators which are easily overlooked during their brief appearance in regular transects (Kruschel and Schultz, 2012). A significant difference in abundance was found between complex mosaic meadows and continuous meadows bordering rock/bordering sand. At the same time, the species richness showed no significant difference among the three habitats. The presence of rocky bottom increased abundance, but surprisingly it did not significantly influence species richness despite increased habitat heterogeneity.

\section{Differences in community structure in three different seascape contexts of Posidonia oceanica meadows}

The null hypothesis of no differences in community structure of fish occurring over three different seascape contexts of Posidonia oceanica meadows was rejected based on nMDS and PERMANOVA results (Fig. 5, Table 5). Significant community differences across habitat arrangements are partly explained by interactions and habitat choice of individual species and their functional roles in the community.

Some of the observed species showed a significant association with one seascape context of $P$. oceanica meadow. For example, Gobius bucchichi/incognitus and Mullus surmuletus were more abundant in continuous meadows bordering sand. Juveniles of Coris julis, Spicara smaris, Symphodus doderleini and Symphodus ocellatus were more abundant in continuous meadows bordering rock, while Serranus cabrilla and Spondyliosoma cantharus were more abundant in mosaic meadows.
That association may be related to their interactions and choice of habitat components, a very similar observation to Rees et al. (2018) in Australia who detected differences in the abundance of species and families among habitats that contributed to the observed multivariate patterns of fish associated to temperate rocky reefs surrounded by seagrass meadows.

In our study, the most obvious observation is that Coris julis, the most abundant species, is common in all three seascape contexts of Posidonia oceanica meadows (Fig. $6)$. However, $C$. julis has higher abundances in mosaic meadows than in continuous meadows bordering sand (on average about 2.5x) and higher abundances in continuous meadows bordering rock vs. sand (on average about 2.3x) (Fig. 6). C. julis juveniles are seen more frequently in continuous $P$. oceanica meadows bordering rock and seem to avoid the mosaic arrangement, which could indicate interference competition with conspecific adults or an increased predation risk within the mosaic meadow. Mosaic meadows are characterized by high abundances of Serranus scriba, Serranus cabrilla and C. julis. They share a sit-and-pursue (Schmitz et al., 1997) or wait-chase (Kruschel and Schultz, 2010) predation mode, specifically promoted by mosaic habitat arrangements. Together, they make up $36 \%$ of the total abundance in the mosaic meadows (Fig. 7). S. cabrilla is thought to be a resident wait-chase predator (Bell and Harmelin-Vivien, 1983) that prefers coralligeneous hard bottoms and rocky reefs (Tunesi and Vacchi, 1993; Seytre et al., 2013), so it might be more abundant in mosaic meadows because it could use the benefit of a structurally more complex habitat for hunting prey (Fernandez et al., 2005). Another aggressive and very abundant (in all three seascape contexts) mesopredator is Diplodus annularis. However, it was seen to avoid the mosaic arrangement, perhaps because it cannot compete for food with its cruise-chase predation mode against the overall more abundant waitchase predators. Active and visual pursuits of prey are less adaptive in highly complex habitats than passive pursuit tactics (Schultz et al., 2009).

The mosaic meadow is further defined by two substrate dwelling labrids (Symphodus ocellatus and Symphodus melanocercus) and two benthopelagic fish species taxa adult Chromis chromis and adult Oblada melanura. It was interesting to note that the juveniles of $O$. melanura have not been observed within the mosaic arrangement. Adult C. chromis are almost twice as abundant in the mosaic arrangement than in the other two seascape contexts. Adult 0 . melanura are four times more abundant in mosaic meadows and 3.2x more abundant in continuous meadows bordering rock than in continuous meadows bordering sand (Fig. 6). The results mentioned above indicate that mosaic meadows' high structural complexity provides various food items and represents a very attractive habitat for such species (Guidetti and Bussotti, 1998). Bonaca and Lipej (2005) found that C. chromis avoided continuous seagrass meadows in general, so the 
higher abundance of this species in mosaic meadows might indicate that the combination of $P$. oceanica and rocky boulders with macroalgae provided a more favorable habitat.

Overall, the highest fish abundances were recorded on transects placed in mosaic meadows with high habitat complexity where seagrasses and rocky-algal reefs are closely interspersed, constituting more habitat combinations and food niches than areas where one of the components is missing. Mosaic meadows are more heterogeneous and probably also more complex habitats, which may explain the highest fish abundances. The proximity of feeding grounds and shelter may enhance fish abundance and richness in seagrass beds, implying that complexity per se may be an essential factor in habitat choice; a combination of habitat types might have a higher value for fish than any individual component of a habitat (Unsworth et al., 2008).

In continuous meadows bordering rock, species such as Symphodus doderleini and Symphodus ocellatus were observed in higher abundances than in the other meadow types, probably because they generally inhabit seagrass beds and rocky reefs (Guidetti, 2000; Frau et al., 2003). Even though the mosaic meadows and continuous meadows bordering rock might look similar and are made of the same two structural elements (seagrass and rocky-algal reefs/boulders), it was interesting to see that in continuous $P$. oceanica meadows bordering rich rocky-algal habitat, $C$. chromis are less abundant than in mosaic meadows, and adult $O$. melanura are replaced by Spicara smaris, a zooplanktivorous fish (Karachle and Sterglou, 2014). Juveniles, observed to be more common in meadows bordering rock, are Diplodus vulgaris and small gobies, which were not observed in the mosaic arrangement.

In continuous meadows bordering sand, the species highly indicative of community structure were Mullus surmulletus and Symphodus melanocercus, which were exclusively observed in P. oceanica bordering sand (13 and 8 times, respectively). M. surmuletus is a bottomdwelling transient predator, frequently found over sand and soft bottoms at depths less than $100 \mathrm{~m}$ (Ben-Tuvia, 1990). Although it is considered associated with $P$. oceanica (Stagličić et al., 2011), it was recorded during our research only if the adjacent habitat was unconsolidated sediments (Fig. 6), consistent with results of Fernández et al. (2005) who found that $M$. surmuletus forages along the seagrass boundaries and in sandy corridors. Gobius bucchichi/incognitus was more abundant in the continuous sand-bordering than in the rock-bordering $P$. oceanica meadows (Fig. 6), probably because it prefers sandy bottoms combined with structured habitat $(P$. oceanica, in this case) (Francour et al., 2011).

What is most interesting about the community within sand-bordering P. oceanica meadows, and seems to define it in contrast to the rock-related arrangements, is the presence of exclusively observed species that may enter the $P$. oceanica meadow from within bare sand habitats in proximity (Jenkins et al., 2015). Examples aside from the above mentioned and relatively abundant $M$. surmulletus, S. melanocercus and G. bucchichi/incognitus are Sarpa salpa, Symphodus rostratus, Thalassoma pavo and juvenile Spondyliosoma cantharus. Juvenile $S$. cantharus choose a completely different habitat from their adult conspecifics. While juveniles are exclusively seen in continuous $P$. oceanica bordering sand, adults are more abundant in mosaic meadows than in continuous meadows bordering rock (14x) and meadows bordering sand (4.7x) (Fig. 6). This situation resembles that of adult and juvenile $C$. julis and might be another example of intraspecific competition and niche partitioning between adults and juveniles (Kimirei et al., 2013).

Species such as Diplodus annularis and Symphodus cinereus are known to occur on bare soft bottoms in the vicinity of seagrasses (Bell and Harmelin-Vivien, 1983), where they can feed. In our study, bare sand patches were absent from mosaic meadows and relatively rare in meadows bordering rock, which might explain the somewhat higher abundances of $D$. annularis and $S$. cinereus in continuous meadows bordering sand.

"Fishes associated with Posidonia oceanica" are often assumed to be uniform communities with local differences in temperature, currents and seafloor characteristics responsible for variation in their structure. However, fish individuals continuously make choices about habitat use as they move through the overall landscape, and their decision to associate with different habitats and habitat arrangements also depends on spatial proximity to habitat relative to their current needs (e.g., food, shelter, mates, predation evasion). Whether suitable structured or unstructured habitat is available in the direct vicinity of seagrass in part determines the community structure of associated fishes. Models of seagrass habitat preference and conservation plans for shallow fish communities in the Adriatic Sea would benefit from a more realistic view of habitat as an intricate mosaic in which seagrass is embedded in many habitat types that influence fish function, movement and preference for seagrass structure.

\section{ACKNOWLEDGMENTS}

This project was partially supported by the Croatian National Science Foundation under the project COREBIO (3107), the European Union FP 7 project COCONET and the Croatian Ministry of Science, Education and Sports under the project 269-0362975-3174. 


\section{UTJECAJ PROSTORNE ORGANIZACIJE ELEME- NATA PODMORSKOG OKOLIŠA NA STRUKTURU ZAJEDNICA RIBA U NASELJIMA MORSKE CV- JETNICE Posidonia oceanica U JADRANSKOM MORU}

\section{SAŽETAK}

Naselja morske cvjetnice Posidonia oceanica igraju važnu ulogu u strukturiranju zajednica riba te utječu na taksonomsku i funkcionalnu raznolikost, brojnost i ponašanje riba. Relativna vrijednost naselja morskih cvjetnica ovisi o prostornoj organizaciji elementa podmorskog okoliša te dostupnosti alternativnih staništa. Međutim, nedovoljno je poznato koji sve čimbenici utječu na strukturu zajednice riba povezanih s ovom morskom cvjetnicom. S ciljem utvrđivanja utjecaja različite prostorne organizacije elementa podmorskog okoliša na zajednice riba, proveden je vizualni cenzus uz pomoć mamca u naseljima cvjetnice $P$. oceanica u hrvatskom dijelu Jadranskog mora. Utvrđen je značajan utjecaj različite prostorne organizacije elementa podmorskog okoliša na strukturu zajednice riba - u rascjepkanim mozaičnim naseljima u kojima se $P$. oceanica isprepliće $\mathrm{s}$ kamenom podlogom obraslom makro-algama zabilježena je značajno veća brojnost riba u odnosu na kontinuirana cjelovita naselja (uz sediment ili uz kamenitu obalu). U radu su predstavljeni dokazi da dostupnost alternativnih strukturiranih staništa $u$ neposrednoj blizini naselja morske cvjetnice $P$. oceanica utječe na strukturu zajednice riba koje u njoj žive. Neophodno je uzeti u obzir kontekst prostornog rasporeda elemenata podmorskog okoliša kojima dominira morska cvjetnica $P$. oceanica prilikom planiranja znanstvenih istraživanja, ali i kod upravljanja priobalnim područjima.

Ključne riječi: morske cvjetnice, ribe, struktura zajednice, vizualni cenzus uz pomoć mamca

\section{REFERENCES}

Anderson, M. J. (2001): A new method for non-parametric multivariate analysis of variance. Austral Ecology, 26, 1, 32-46.

Bell, J. D., Harmelin-Vivien, M. (1982): Fish fauna of French Mediterranean Posidonia oceanica seagrass meadows I. Community structure. Tethys, 10, 4, 337-347.

Bell, J. D., Harmelin-Vivien, M. (1983): Fish fauna of French Mediterranean Posidonia oceanica seagrass meadows. II: Feeding habits. Tethys, 11, 1, 1-14.

Ben-Tuvia, A. (1990): Mullidae. pp. 827-829. In: Quéro J. C., Hureau J. C., Karrer, C. A. (eds.): Checklist of the Eastern Tropical Atlantic (Clofeta), Vol II. UNESCO.

Bonaca, M. O., Lipej, L. (2005): Factors affecting habitat occupancy of fish assemblage in the Gulf of Trieste
(Northern Adriatic Sea): Marine Ecology, 26, 1, 42-53.

Borg, J., Schembri, P. (1995): The state of Posidonia oceanica (L.) Delile meadows in the Maltese islands (Central Mediterranean): Rapp. Comm. Int. Mer Médit., 34, 123.

Bos, A.R., Bouma, TJ, de Kort, G.L., van Katwijk, M.M. (2007): Ecosystem engineering by annual intertidal seagrass beds: sediment accretion and modification. Estuarine, Coastal and Shelf Science, 74, 1-2, 344-348.

Boudouresque C.F., Bernard, G., Bonhomme, P., Charbonnel, E., Diviacco, G., Meinesz, A., Pergent, G., Pergent-Martini, C., Ruitton, S., Tunesi, L. (2012): Préservation et conservation des herbiers à Posidonia oceanica. In RAMOGE pub (Vol. 335), pp 1-202.

Chambers, J. M., Freeny, A. E., Heiberger, R. M. (2017): Analysis of variance; designed experiments. pp. 145-193. In: T.J Hastie (eds.): Statistical models in S. Routledge.

Connolly, M., Hindell, J. (2006): Review of nekton patterns and ecological processes in seagrass landscapes. Estuarine, Coastal and Shelf Science, 68, 3-4, 433-444.

Den Hartog, C. (1979): Seagrasses and seagrass ecosystems, an appraisal of the research approach. Aquatic Botany, 7, 105-117.

Deudero, S., Morey, G., Frau, A, Moranta, J., Moreno, I. (2008): Temporal trends of littoral fishes at deep Posidonia oceanica seagrass meadows in a temperate coastal zone. Journal of Marine Systems, 70, 1-2, 182195.

Dorenbosch, M, Grol, M. G. G., Nagelkerken, I., Velde, G. (2006): Different surrounding landscapes may result in different fish assemblages in east African seagrass beds. Hydrobiologia, $563,1,45-60$.

Dorenbosch, M. (2004): The relationship of reef fish densities to the proximity of mangrove and seagrass nurseries. Estuarine, Coastal and Shelf Science, 60, 1, 37-48.

Dorenbosch, Martijn, Nagelkerken, I., Velde, G. Van Der. (2007): Influence of habitat configuration on connectivity between fish assemblages of Caribbean seagrass beds, mangroves, and coral reefs. Marine Ecology Progress Series, 334, 103-116.

Duarte, C.M., Chiscano, C.L. (1999): Seagrass biomass and production: a reassessment. Aquatic Botany, 65, 1-4, 159-174.

Eyre, B.D., Ferguson, A.J., Webb, A., Maher, D., Oakes, J.M. (2011): Denitrification, N-fixation, and nitrogen and phosphorus fluxes in different benthic habitats and their contribution to the nitrogen and phosphorus budgets of a shallow oligotrophic sub-tropical coastal system (southern Moreton Bay, Australia): Biogeochemistry, 102, 1-3, 111-133.

Faith, D. P., Minchin, P. R., Belbin, L. (1987): Compositional dissimilarity as a robust measure of ecological distance. Vegetatio, 69, 3, 57-68.

Faria, J.C., Jelihovschi, E.G., Allaman, I.B. (2018): Conventional Tukey Test. UESC, Ilheus, Brasil. 
Fernandez, T., Milazzo, M., Badalamenti, F., Danna, G. (2005): Comparison of the fish assemblages associated with after the partial loss and consequent fragmentation of the meadow. Estuarine, Coastal and Shelf Science, 65, 4, 645-653.

Francour, P. (1997): Fish assemblages of Posidonia oceanica beds at Port-Cros (France, NW Mediterranean): assessment of composition and long-term fluctuations by visual census. Marine Ecology, 18, 2, 157-173.

Francour, P., Bilecenoglu, M., Bariche, M., Tunesi, L., Goren, M. (2011): Gobius bucchichi. The IUCN Red List of Threatened Species 2011: e. T194873A8911208.

Frau, A., Alou, L., Deudero, S., Cerdeño, S. (2003): No habitat preference in mixed meadows and rocky bottoms for Mediterranean Labridae and Sparidae fish species. Boletin Instituto Español de Oceanografia, 19, 1, 483-492.

Gilby, B., Olds, A., Connolly, R., Maxwell, P., Henderson, C., Schlacher, T. (2018): Seagrass meadows shape fish assemblages across estuarine seascapes. Marine Ecology Progress Series, 588, 179-189.

Graham, N. A. J., Nash, K. L. (2013): The importance of structural complexity in coral reef ecosystems. Coral Reefs, 32, 2, 315-326.

Guidetti, P. (2000): Differences among fish assemblages associated with nearshore Posidonia oceanica seagrass beds, rocky-algal reefs and unvegetated sand habitats in the Adriatic Sea. Estuarine, Coastal and Shelf Science.

Guidetti, P., Bussotti, S., Conti, M. (1998): Fish fauna of the Genoa-Quinto Posidonia oceanica bed (Ligurian Sea, North-Western Mediterranean): Rapports Commission international Mer Méditerranée, 35, 546-547.

Hemminga, M.A., Duarte, C.M. (2000): Seagrass ecology. Cambridge University Press.

Henderson, C. J., Gilby, B. L., Lee, S. Y., Stevens, T. (2017): Contrasting effects of habitat complexity and connectivity on biodiversity in seagrass meadows. Marine Biology, 164, 5, 117.

Jenkins, G. P., Kenner, T., Brown, A., Coleman, R. (2015): Fish assemblages in locations with alternative structured habitats in an eelgrass, Zostera, dominated bay: Biodiversity value and potential for refuge. Estuarine, Coastal and Shelf Science, 161, 25-37.

Jones, G. P. (1984): The influence of habitat and behavioral interactions on the local distribution of the wrasse, Pseudolabrus celidotus. Environmental Biology of Fishes.

Kalogirou, S., Corsini-Foka, M., Sioulas, A., Wennhage, H., Pihl, L. (2010): Diversity, structure and function of fish assemblages associated with Posidonia oceanica beds in an area of the eastern Mediterranean Sea and the role of non-indigenous species. Journal of Fish Biology, 77, 10, 2338-2357.

Karachle, P. K., Stergiou, K. I. (2014): Diet and feeding habits of Spicara maena and S. smaris (Pisces, Osteichthyes, Centracanthidae) in the North Aegean Sea. 55, 1, 75-84.
Kimirei, I. A., Nagelkerken, I., Trommelen, M., Blankers, P., Van Hoytema, N., Hoeijmakers, D., Huijbers, C. M., Mgaya, Y. D., Rypel, A. (2013): What drives ontogenetic niche shifts of fishes in coral reef ecosystems? Ecosystems, 16, 5, 783-796.

Kopp, D., Bouchon-Navaro, Y., Louis, M., Bouchon, C. (2007): Diel differences in the seagrass fish assemblages of a Caribbean island in relation to adjacent habitat types. Aquatic Botany.

Kruschel, C., Schultz, S. (2010): Lure-assisted visual census: a new method for quantifying fish abundance, behavior, and predation risk in shallow coastal habitats. Marine and Freshwater Research, 61, 12, 1349.

Kruschel, C., Schultz, S. T. (2012): Use of a lure in visual census significantly improves probability of detecting wait-ambushing and fast cruising predatory fish. Fisheries Research, 123-124, 70-77.

Laegdsgaard, P., Johnson, C. (2001): Why do juvenile fish utilize mangrove habitats? Journal of Experimental Marine Biology and Ecology.

McArdle, B.H., Anderson, M.J. (2001): Fitting multivariate models to community data: a comment on distancebased redundancy analysis. Ecology, 82, 1, 290-297.

McLeod, E., Chmura, G.L., Bouillon, S., Salm, R., Björk, M., Duarte, C.M., Lovelock, C.E., Schlesinger, W.H., Silliman, B.R. (2011): A blueprint for blue carbon: toward an improved understanding of the role of vegetated coastal habitats in sequestering $\mathrm{CO}_{2}$. Frontiers in Ecology and the Environment, 9, 10, 552-560.

Minchin, P. R. (1987): An evaluation of the relative robustness of techniques for ecological ordination. Vegetatio, 69, 1-3, 89-107.

Moranta, J., Palmer, M., Morey, G., Ruiz, A., Moralesnin, B. (2006): Multi-scale spatial variability in fish assemblages associated with Posidonia oceanica meadows in the Western Mediterranean Sea. Estuarine, Coastal and Shelf Science, 68, 3-4, 579-592.

Mouillot, D., Culioli, J., Lepretre, A., Tomasini, J. (1999): Dispersion Statistics and Sample Size Estimates for Three Fish Species (Symphodus ocellatus, Serranus scriba and Diplodus annularis) in the Lavezzi Islands Marine Reserve (South Corsica, Mediterranean Sea): Marine Ecology, 20, 1, 19-34.

Nagelkerken, I. (2000): Importance of Mangroves, Seagrass Beds and the Shallow Coral Reef as a Nursery for Important Coral Reef Fishes, Using a Visual Census Technique. Estuarine, Coastal and Shelf Science, 51, 1, 31-44.

Nagelkerken, I., Kleijnen, S., Klop, T., Van Den Brand, RACJ, de La Moriniere, E.C., Van der Velde, G. (2001): Dependence of Caribbean reef fishes on mangroves and seagrass beds as nursery habitats: a comparison of fish faunas between bays with and without mangroves/ seagrass beds. Marine Ecology Progress Series, 214, 225-235.

Nakamura, Y., Sano, M. (2004): Overlaps in habitat use of fishes between a seagrass bed and adjacent coral 
and sand areas at Amitori Bay, Iriomote Island, Japan: Importance of the seagrass bed as juvenile habitat. Fisheries Science, 70, 5, 788-803.

Olds, A. D., Albert, S., Maxwell, P. S., Pitt, K. A., Connolly, R. M. (2013): Mangrove-reef connectivity promotes the effectiveness of marine reserves across the western Pacific. Global Ecology and Biogeography, 22, 9, 10401049.

Orth, R.J., Heck, K.L. Jr., van Montfrans, J. (1984): Faunal communities in seagrass beds: a review of the influence of plant structure and prey characteristics on predatorprey relationships. Estuaries, 7, 339-350.

Pittman, S. J., Caldow, C., Hile, S. D., Monaco, M. E. (2007): Using seascape types to explain the spatial patterns of fish in the mangroves of SW Puerto Rico. Marine Ecology Progress Series, 348, 273-284.

Procaccini, G., Buia, M. C., Gambi, M. C., Perez, M., Pergent, G., Pergent-Martini, C., Romero, J. (2003): The seagrasses of the Western Mediterranean. In: Green, E. P., Short, F. T. (eds.): pp. 48-58. World Atlas of Seagrasses. UNEP World Conservation Monitoring Center. University of California Press. Berkley, USA.

R Development Core Team, R. (2017): R: A Language and Environment for Statistical Computing.

Rees, M.J., Knott, N.A., Davis, A.R. (2018): Habitat and seascape patterns drive spatial variability in temperate fish assemblages: implications for marine protected areas. Marine Ecology Progress Series, 607, 171-186.

Salita, J. T., Ekau, W., Saint-Paul, U. (2003): Field evidence on the influence of seagrass landscapes on fish abundance in Bolinao, northern Philippines. Marine Ecology Progress Series.

Schmitz, O. J., Beckerman, A. P., O'Brien, K. M. (1997): Behaviorally mediated trophic cascades: Effects of predation risk on food web interactions. Ecology, 78, 5, 1388-1399.

Schultz, S., Kruschel, C., Bakran-Petricioli, T. (2009): Influence of seagrass meadows on predator-prey habitat segregation in an Adriatic lagoon. Marine Ecology Progress Series, 374, 85-99.

Seytre, C., Vanderklift, M. A., Bodilis, P., Cottalorda, J.M., Gratiot, J., Francour, P. (2013): Assessment of commercial and recreational fishing effects on trophic interactions in the Cap Roux area (north-western Mediterranean): Aquatic Conservation: Marine and Freshwater Ecosystems, 23, 2, 189-201.
Stagličić, N., Matić-Skoko, S., Pallaoro, A., Grgičević, R., Kraljević, M., Tutman, P., Dragičević, B., Dulčić, J. (2011): Long-term trends in the structure of eastern Adriatic littoral fish assemblages: Consequences for fisheries management. Estuarine, coastal and shelf science, 94, 3, 263-271.

Telesca, L., Belluscio, A., Criscoli, A., Ardizzone, G., Apostolaki, E.T., Fraschetti, S., Gristina, M., Knittweis, L., Martin, C.S., Pergent, G., Alagna, A. (2015): Seagrass meadows (Posidonia oceanica) distribution and trajectories of change. Scientific reports, 5, p.12505.

Tunesi, L., Vacchi, M. (1993): Indagini visuali in immersione nell'area marina di Portofino: applicazione di un metodo per lo studio dei popolamenti ittici. Biologia Marina, 355-360.

Unsworth, R.K., De León, P.S., Garrard, S.L., Jompa, J., Smith, D.J., Bell, JJ (2008): High connectivity of IndoPacific seagrass fish assemblages with mangrove and coral reef habitats. Marine Ecology Progress Series, 353, 213-224.

Valle, C., Bayle-Sempere, J. (2009): Effects of a marine protected area on fish assemblage associated with Posidonia oceanica seagrass beds: temporal and depth variations. Journal of Applied Ichthyology, 25, 5, 537544.

Waycott, M., Duarte, C.M., Carruthers, T.J., Orth, R.J., Dennison, W.C., Olyarnik, S., Calladine, A., Fourqurean, J.W., Heck, K.L., Hughes, A.R., Kendrick, G.A. (2009): Accelerating loss of seagrasses across the globe threatens coastal ecosystems. Proceedings of the national academy of sciences, 106, 30, 12377-12381.

Zubak, I., Cizmek, H., Mokos, M. (2020): Posidonia oceanica lower depth limits along a latitudinal gradient in the eastern Adriatic Sea. Botanica Marina, 63(3), 209-214.

Zubak, I., Kruschel, C., Schultz, S. T. (2017): Predators structure fish communities in Posidonia oceanica meadows: Meta-analysis of available data across the Mediterranean basin. Marine Ecology Progress Series, 566, 145-157. 


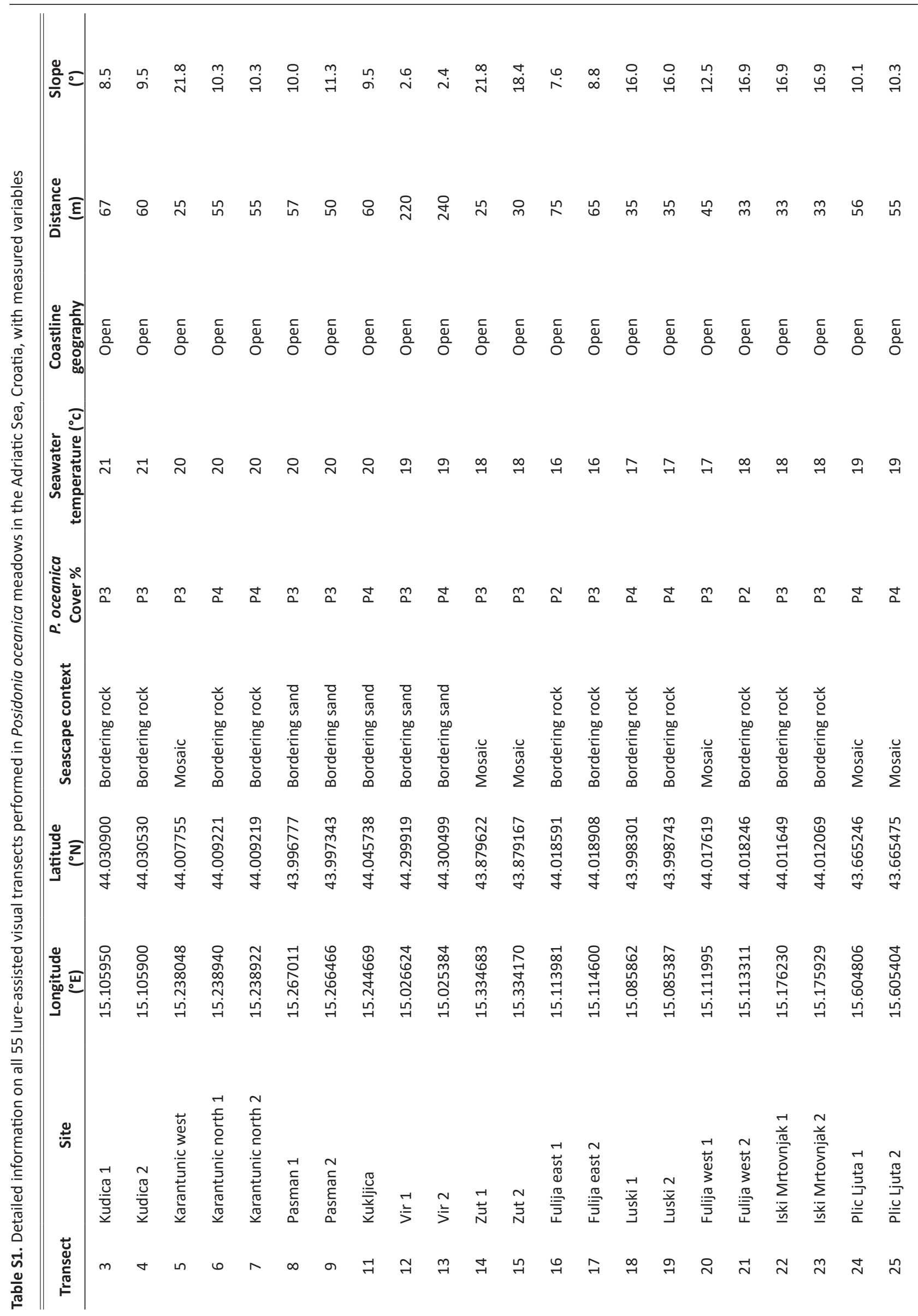




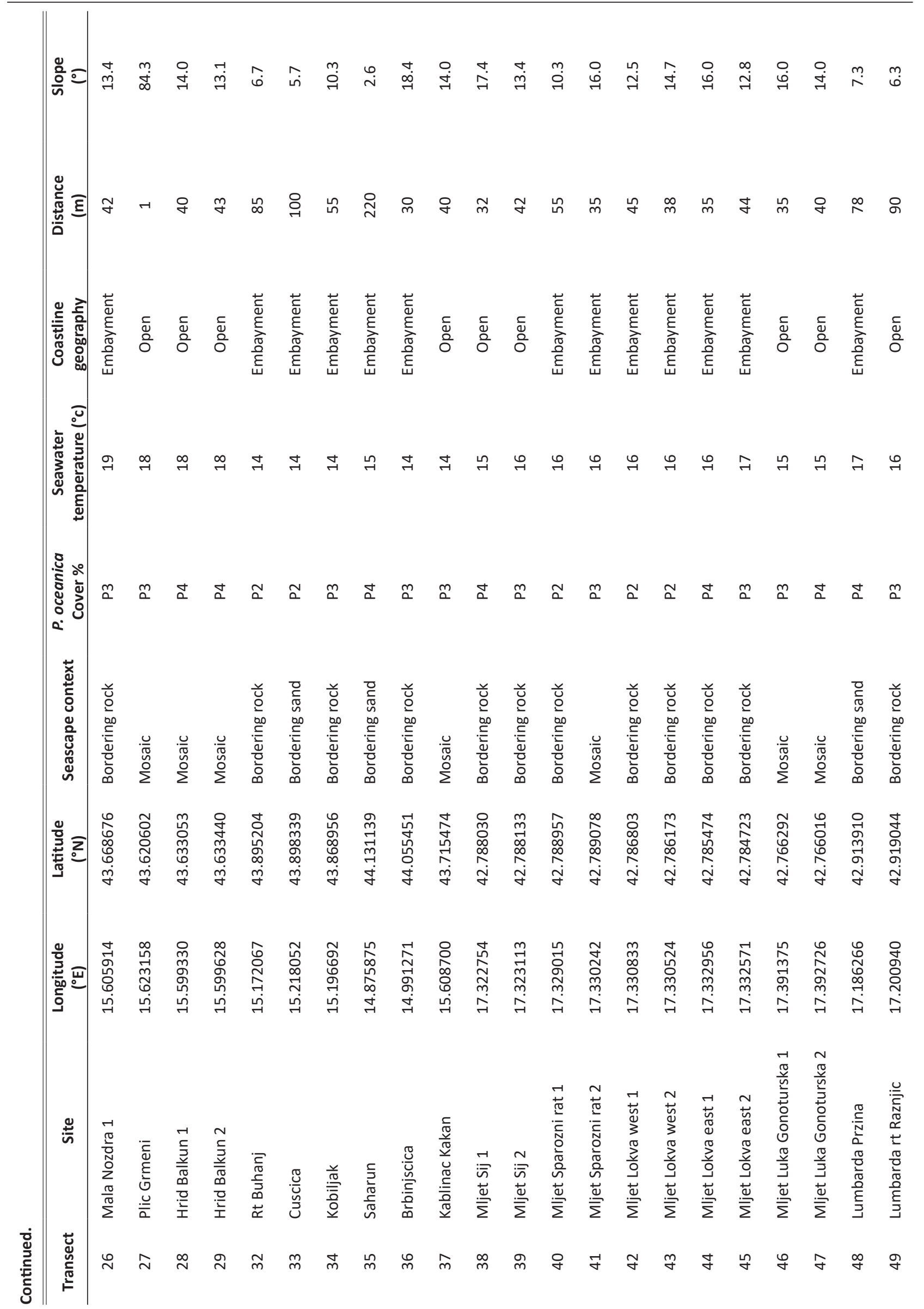




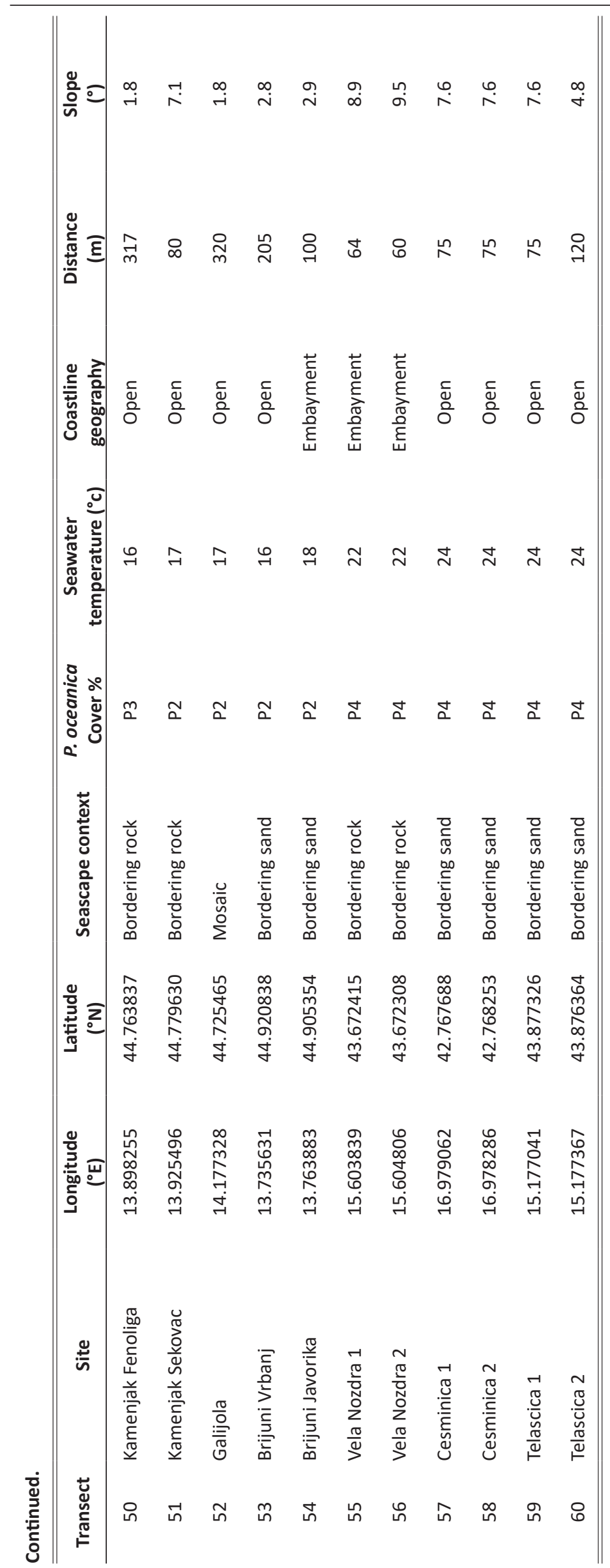

